\title{
ANALISIS PENGUKURAN TOTAL EFEKTIVITAS MESIN FLAME CUTTING DAN PLASMA CUTTING PADA PERUSAHAAN INDUSTRI STRATEGIS
}

\author{
Arif Junisman Mendrofa, Tri Mulyanto \\ Program Studi Teknik Mesin, Fakultas Teknologi Industri, Universitas Gunadarma \\ e-mail: arifjunismanm@gmail.com, tri_mulyanto@staff.gunadarma.ac.id
}

\begin{abstract}
ABSTRAK
Pengukuran total efektivitas mesin flame cutting dan plasma cutting dilakukan menggunakan metode dalam konsep TPM yaitu metode Overall Equipment Effectiveness (OEE). Metode yang juga digunakan adalah Net Equipment Effectiveness (NEE), dan Total Effective Equipment Performance (TEEP). Metode OEE tersebut didasarkan pada faktor availability, performance efficiency, dan rate of quality product. Sementara itu, nilai NEE didasarkan pada faktor up time, performance efficiency, dan rate of quality product. TEEP didasarkan pada faktor loading portion dan nilai OEE itu sendiri. Berdasarkan hasil pembahasan, persentase OEE berturut-turut sebesar 73,7\%, 72,2\%, 67,6\%, 68,7\%, dan 73,1\%. Persentase NEE berturutturut sebesar 74,0\%, 71,9\%, 67,2\%, 68,4\%, dan 72,9\%. Persentase TEEP berturut-turut sebesar 57,0\%, 59,8\%, 54,5\%, 59,6\%, dan 56,6\%. Persentase equipment failures loss berturutturut sebesar 2,1\%, 4,3\%, 4,9\%, 4,6\%, dan 2,6\%. Persentase setup and adjustment loss berturut-turut sebesar $1,3 \%, 1,3 \%, 1,3 \%, 1,2 \%$, dan 1,2\%. Persentase idling and minor stoppages loss berturut-turut sebesar 0,8\%, 0,8\%, 0,9\%, 0,9\%, dan 0,8\%. Persentase reduce speed loss berturut-turut sebesar 13,3\%, 12,7\%, 12,4\%, 13,1\%, dan 12,7\%. Persentase defect loss berturut-turut sebesar 9,0\%, 8,9\%, 13,1\%, 11,8\%, dan 9,7\%. Sementara itu, persentase reduce yield loss berturut-turut sebesar 1,0\%, 0,7\%, 1,9\%, 1,4\%, dan 0,9\%. Faktor-faktor penyebab menurunnya efektivitas akibat tingginya reduce speed losses antara lain faktor manusia, metode, mesin, dan material. Sementara itu, faktor-faktor penyebab menurunnya efektivitas akibat tingginya defect losses, antara lain faktor manusia, metode, mesin, material, dan lingkungan. Usulan untuk meningkatkan efektivitas kerja mesin flame cutting dan plasma cutting terbagi dalam beberapa faktor sesuai penyebab menurunnya efektivitas mesin yang terjadi.
\end{abstract}

Kata kunci: Efektivitas, Mesin, TPM, OEE, NEE, TEEP.

\begin{abstract}
The measurement of total effectiveness for flame cutting and plasma cutting machine used method in the concept of TPM is Overall Equipment Effectiveness (OEE). The other method also used is Net Equipment Effectiveness (NEE), and Total Effective Equipment Performance (TEEP). OEE method based on availability, performance efficiency, and rate of quality product. Meanwhile, the value of NEE based on up time, performance efficiency, and rate of quality product. TEEP method based on the loading portion and the OEE value. Based on the results, the percentage of OEE is $73.7 \%, 72.2 \%, 67.6 \%, 68.7 \%$, and $73.1 \%$. The percentage of NEE is $74.0 \%, 71.9 \%, 67.2 \%, 68.4 \%$, and $72.9 \%$. The percentage of TEEP is $57.0 \%, 59.8 \%$, $54.5 \%, 59.6 \%$, and $56.6 \%$. The percentage of equipment failures loss is $2.1 \%, 4.3 \%, 4.9 \%$, $4.6 \%$, and $2.6 \%$. The percentage of setup and adjustment loss from January to May 2016 is $1.3 \%, 1.3 \%, 1.3 \%, 1.2 \%$, and $1.2 \%$. The percentage of idling and minor stoppages loss from January to May 2016 is $0.8 \%, 0.8 \%, 0.9 \%, 0.9 \%$, and $0.8 \%$. The percentage of reduce speed loss from January to May 2016 is 13.3\%, 12.7\%, 12.4\%, 13.1\%, and 12.7\%. The percentage of defect loss from January to May 2016 is $9.0 \%$, 8.9\%, 13.1\%, 11.8\%, and 9.7\%. Meanwhile, the percentage of reduce yield loss from January to May 2016 is 1.0\%, 0.7\%, 1.9\%, 1.4\%, and $0.9 \%$. The factors that cause decrease of effectiveness due to the high of reduce speed losses among others the human factor, method, machine, and material. Meanwhile the factors that cause decrease of effectiveness due to the high defect losses among others the human factor, method, machine, material and environment. To proposed the increase effectiveness of work machine flame cutting and plasma cutting divided into few factors appropriate with decrease of machine effectiveness that consist.
\end{abstract}

Keywords: Effectiveness, Machine, TPM, OEE, NEE, TEEP. 


\section{PENDAHULUAN}

Perawatan perlu dilakukan dengan baik untuk membantu kelancaran proses produksi sehingga meminimalisasi kerugian yang ada. Gangguan yang terjadi pada mesin dan peralatan dalam periode tertentu dapat terjadi karena perusahaan belum pernah melakukan pengukuran efektivitas mesin dalam sistem perawatan tersebut. Efektivitas mesin dan peralatan dapat menunjukkan produktivitas mesin dan peralatan tersebut terhadap produk yang telah diproduksi [1-6].

Salah satu konsep yang dapat digunakan untuk mengetahui dan meningkatkan produktivitas yaitu konsep Total Productive Maintenance (TPM). TPM merupakan suatu aktivitas perawatan menyeluruh dari semua personil yang bertujuan mencapai zero breakdown, zero defect, dan zero accident untuk memaksimalkan efisiensi penggunaan mesin dan alat [7-12].

Perusahaan industri strategis dalam hal ini merupakan perusahaan yang bergerak khususnya dalam bidang produk militer dan komersial di Indonesia [13]. Salah satu kegiatan produksi yang berlangsung didivisi kendaraan khusus pada perusahaan industri strategis tersebut yaitu proses produksi komponen utama dari produk kendaraan taktis varian MBDA 4 x 4 yang terbuat dari plat ST 37. Mesin yang digunakan untuk produksi badan kendaraan tersebut diantaranya mesin las, mesin tekuk, mesin roll plat, mesin flame cutting dan plasma cutting, dari sekian mesin tersebut yang pernah mengalami gangguan pada bagian produksi 1 divisi kendaraan khusus adalah mesin flame cutting dan plasma cutting. Mesin flame cutting dan plasma cutting digunakan untuk kegiatan pemotongan plat besi hitam dengan tebal yang berbeda-beda.

Pengukuran total efektivitas kerja mesin flame cutting dan plasma cutting dilakukan menggunakan metode dalam konsep TPM yaitu metode Overall Equipment Effectiveness (OEE) [8,14-18]. Metode yang juga digunakan dalam pengukuran total efektivitas kerja mesin flame cutting dan plasma cutting adalah Net Equipment Effectiveness (NEE) [15], dan Total Effective Equipment Productivity (TEEP) [9]. Metode OEE, NEE, dan TEEP dipilih karena belum dilakukannya pengukuran efektivitas kerja mesin pada mesin flame cutting dan plasma cutting, serta data yang diperoleh juga terbatas apabila menggunakan metode lain.

Proses setelah diketahui rendahnya nilai OEE, NEE, dan TEEP adalah dilakukannya perhitungan six big losses untuk menentukan kerugian terbesar yang mengakibatkan rendahnya total efektivitas kerja mesin flame cutting dan plasma cutting. Proses terakhir yaitu ditentukannya faktor-faktor yang mempengaruhi penyebab menurunnya total efektivitas kerja mesin flame cutting dan plasma cutting, sehingga dapat diberikan masukan atau saran yang tepat untuk meningkatkan efektivitas kerja mesin tersebut dan mengurangi kerugian yang terjadi.

Perumusan masalah terkait penelitian yang dilakukan yaitu bagaimana mengukur total efektivitas kerja mesin flame cutting dan plasma cutting, bagaimana mengukur six big losses dari mesin flame cutting dan plasma cutting, serta mengidentifikasi faktor-faktor yang mempengaruhi penyebab menurunnya efektivitas mesin flame cutting dan plasma cutting.

Tujuan penelitian yang dilakukan pada perusahaan industri strategis tersebut yaitu mengukur total efektivitas kerja mesin flame cutting dan plasma cutting yang dilakukan dibagian produksi 1 divisi kendaraan khusus pada perusahaan industri strategis, mengukur six big losses dari mesin flame cutting dan plasma cutting, mengidentifikasi faktor-faktor yang mempengaruhi penyebab menurunnya efektivitas mesin flame cutting dan plasma cutting. Tujuan terakhir dari penelitian ini adalah memberikan usulan untuk meningkatkan efektivitas kerja mesin flame cutting dan plasma cutting. 


\section{METODE PENELITIAN}

Tahapan penelitian merupakan tahapan-tahapan yang jelas dan disusun secara sistematis dalam proses penelitian. Tahapan tersebut digambarkan pada kerangka penelitian yang ditampilkan pada Gambar berikut.

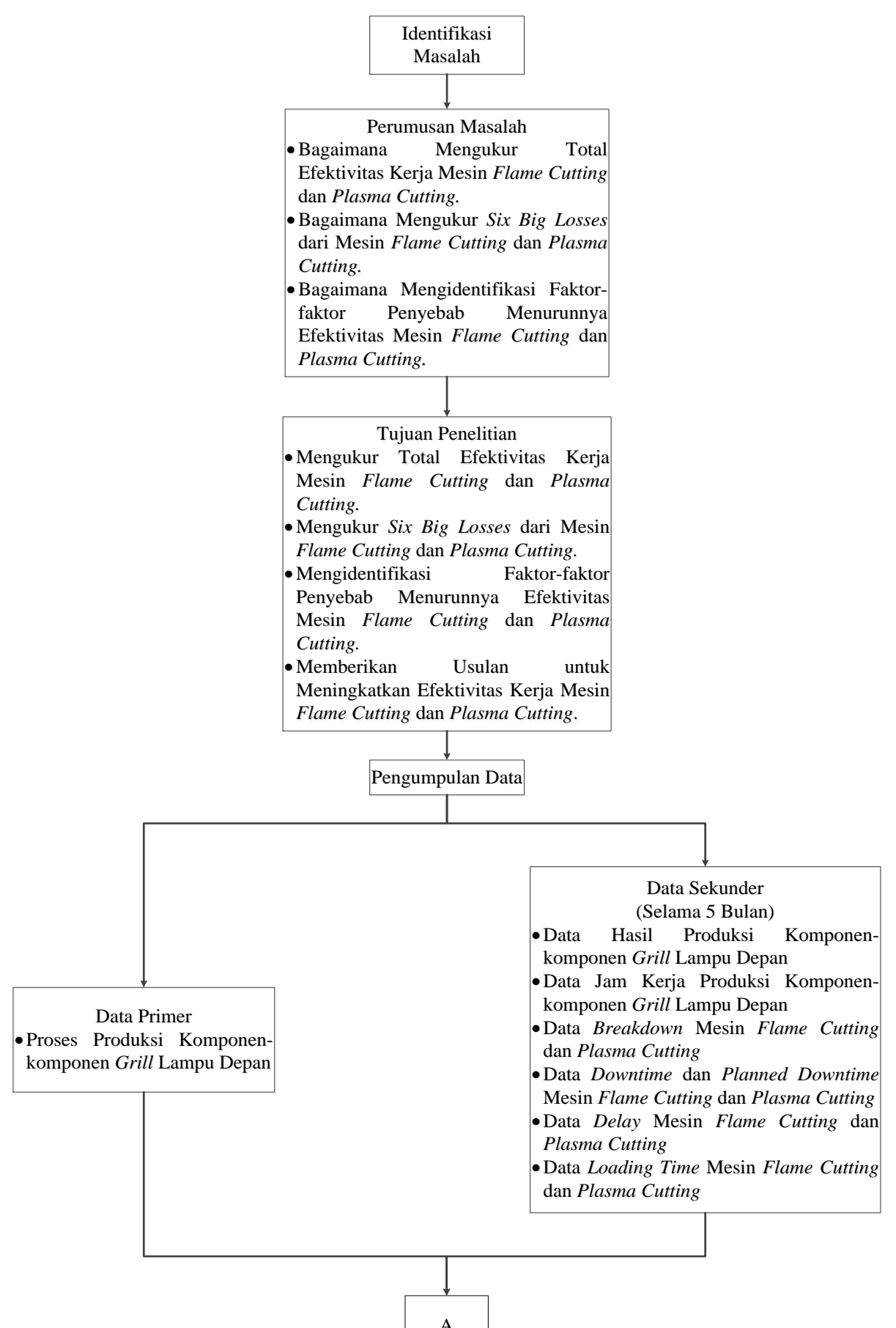

Gambar 1. Kerangka Penelitian 
Analisis Pengukuran Total Efektivitas Mesin Flame Cutting dan Plasma Cutting pada Perusahaan Industri Strategis

\section{Arif Junisman Mendrofa, Tri Mulyanto}

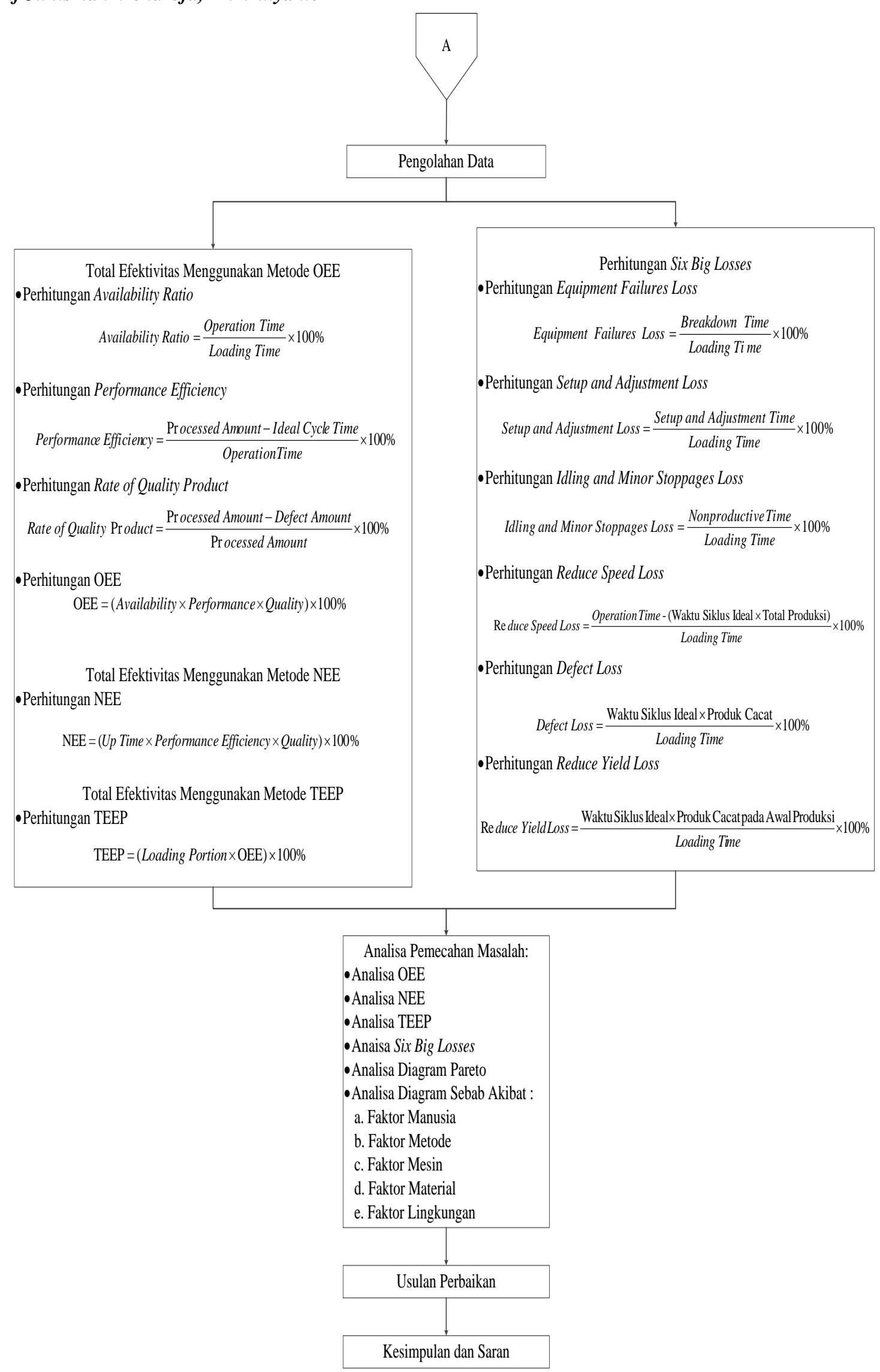

Lanjutan Gambar 1. Kerangka Penelitian 


\section{HASIL DAN PEMBAHASAN}

Penelitian dilakukan pada mesin utama yang digunakan untuk pemotongan plat besi hitam yaitu mesin flame cutting dan plasma cutting. Mesin flame cutting dan plasma cutting dipilih karena mempertimbangkan pentingnya mesin tersebut selama proses produksi berlangsung dan terkhusus pada lini fabrikasi. Apabila terjadi kerusakan pada mesin flame cutting dan plasma cutting maka tidak dapat dilakukannya pemotongan plat besi hitam, akibatnya tidak dapat dilanjutkan pada proses selanjutnya dan proses produksi menjadi terhenti.

\section{Perhitungan Nilai OEE}

OEE sebagai salah satu alat pengukuran efektivitas kerja mesin pada TPM berguna untuk menghilangkan berbagai kerugian yang terjadi dengan dikelompokkan menjadi tiga parameter, antara lain availability ratio, performance efficiency, serta rate of quality product.

Availability ratio merupakan salah satu parameter untuk menentukan nilai OEE berdasarkan ketersediaan mesin. Perhitungan availability ratio dilakukan untuk mengukur efektivitas mesin flame cutting dan plasma cutting dari ketersediaan mesin tersebut dalam memproduksi komponen-komponen grill lampu depan. Availability ratio juga menunjukkan rasio dari operation time terhadap waktu operasi yang tersedia (loading time). Berikut hasil perhitungan availability ratio.

Tabel 1. Hasil Perhitungan Availability Ratio

\begin{tabular}{lcccc}
\hline \multicolumn{1}{c}{ Bulan } & $\begin{array}{c}\text { Loading Time } \\
\text { (Menit) }\end{array}$ & $\begin{array}{c}\text { Downtime } \\
\text { (Menit) }\end{array}$ & $\begin{array}{c}\text { Operation Time } \\
\text { (Menit) }\end{array}$ & $\begin{array}{c}\text { Availability Ratio } \\
\text { (\%) }\end{array}$ \\
\hline Januari 2016 & 29835 & 1173 & 28662 & 96,1 \\
Februari 2016 & 29940 & 1844,4 & 28095,6 & 93,8 \\
Maret 2016 & 31275 & 2164,8 & 29110,2 & 83,1 \\
April 2016 & 32280 & 2080,2 & 30199,8 & 93,6 \\
Mei 2016 & 30015 & 1345,2 & 28669,8 & 95,5 \\
\hline
\end{tabular}

Perhitungan untuk menentukan availability ratio pada bulan Januari 2016 sebagai berikut:

$$
\begin{aligned}
\text { Availability Ratio } & =\frac{\text { Operation Time }}{\text { Loading Time }} \times 100 \% \\
& =\frac{28662 \text { Menit }}{29835 \text { Menit }} \times 100 \% \\
& =96,1 \%
\end{aligned}
$$

Perhitungan performance efficiency berguna untuk mengukur rasio yang menggambarkan kemampuan mesin flame cutting dan plasma cutting dalam memproduksi komponen-komponen grill lampu depan. Nilai performance efficiency dapat dihitung apabila telah diketahui hasil perhitungan persentase jam kerja, waktu siklus ideal, serta diketahui jumlah produk OK. Berikut hasil perhitungan persentase performance efficiency terlihat pada Tabel 9.

Tabel 2. Hasil Perhitungan Performance Efficiency

\begin{tabular}{lcccc}
\hline \multicolumn{1}{c}{ Bulan } & $\begin{array}{c}\text { Processed Amount } \\
\text { (Unit) }\end{array}$ & $\begin{array}{c}\text { Waktu Siklus Ideal } \\
\text { (Menit/Unit) }\end{array}$ & $\begin{array}{c}\text { Operation Time } \\
\text { (Menit) }\end{array}$ & $\begin{array}{c}\text { Performance Efficiency } \\
(\%)\end{array}$ \\
\hline Januari 2016 & 789 & 31,28 & 28662 & 86,1 \\
Februari 2016 & 740 & 32,82 & 28095,6 & 86,4 \\
Maret 2016 & 732 & 34,47 & 29110 & 86,7 \\
April 2016 & 731 & 35,54 & 30199,8 & 86,0 \\
Mei 2016 & 786 & 31,61 & 28669,8 & 86,7 \\
\hline
\end{tabular}


Analisis Pengukuran Total Efektivitas Mesin Flame Cutting dan Plasma Cutting pada Perusahaan Industri Strategis

\section{Arif Junisman Mendrofa, Tri Mulyanto}

Perhitungan untuk menentukan nilai performance efficiency pada bulan Januari 2016 sebagai berikut:

$$
\begin{aligned}
\text { Performance Eff. } & =\left(\frac{\text { Processed Amount } \times \text { Waktu Siklus Ideal }}{\text { Operation Time }}\right) \times 100 \% \\
& =\left(\frac{780 \text { Unit } \times 31,28 \text { Menit } / \text { Unit }}{28662 \text { Menit }}\right) \times 100 \% \\
& =86,1 \%
\end{aligned}
$$

Rate of quality product merupakan rasio untuk menggambarkan kemampuan mesin flame cutting dan plasma cutting dalam menghasilkan jumlah unit komponen-komponen grill lampu depan yang bagus sesuai dengan spesifikasi yang diharapkan. Berikut hasil perhitungan rate of quality product terlihat pada Tabel 3.

Tabel 3. Hasil Perhitungan Rate of Quality Product

\begin{tabular}{lccc}
\hline \multicolumn{1}{c}{ Bulan } & $\begin{array}{c}\text { Processed Amount } \\
\text { (Unit) }\end{array}$ & $\begin{array}{c}\text { Defect Amount } \\
\text { (Unit) }\end{array}$ & $\begin{array}{c}\text { Rate of Quality Product } \\
\text { (\%) }\end{array}$ \\
\hline Januari 2016 & 789 & 86 & 89,1 \\
Februari 2016 & 740 & 81 & 89,1 \\
Maret 2016 & 732 & 119 & 83,7 \\
April 2016 & 731 & 107 & 85,4 \\
Mei 2016 & 786 & 92 & 88,3 \\
\hline
\end{tabular}

Perhitungan rate of quality product pada bulan Januari 2016 sebagai berikut:

Rate of Quality Product $=\left(\frac{\text { Processed Amount-Defect Amount }}{\text { Processed Amount }}\right)$

$$
\begin{aligned}
& =\left(\frac{789 \text { Unit }-86 \text { Unit }}{789 \text { Unit }}\right) \times 100 \% \\
& =89,1 \%
\end{aligned}
$$

Nilai OEE diperoleh dari perkalian ketiga faktor seperti availability ratio, performance efficiency, serta rate of quality product. Berikut hasil perhitungan OEE.

Tabel 4. Hasil Perhitungan Overall Equipment Effectiveness

\begin{tabular}{lcccc}
\hline \multicolumn{1}{c}{ Bulan } & $\begin{array}{c}\text { Availability Ratio } \\
(\boldsymbol{\%})\end{array}$ & $\begin{array}{c}\text { Performance Efficiency Rate of Quality Product } \\
(\boldsymbol{\%})\end{array}$ & $\begin{array}{c}\text { OEE } \\
(\boldsymbol{\%})\end{array}$ \\
\hline Januari 2016 & 96,1 & 86,1 & 89,1 & 73.7 \\
Februari 2016 & 93,8 & 86,4 & 89,1 & 72,2 \\
Maret 2016 & 93,1 & 86,7 & 83,7 & 67,6 \\
April 2016 & 93,6 & 86,0 & 85,4 & 68,7 \\
Mei 2016 & 95,5 & 86,7 & 88,3 & 73,1 \\
\hline
\end{tabular}

Perhitungan nilai OEE pada bulan Januari 2016 sebagai berikut:

$$
\begin{aligned}
\text { OEE } & =(\text { Availability } \times \text { Performance Efficiency } \times \text { Quality }) \times 100 \% \\
& =(0,961 \times 0,861) \times 100 \% \\
& =73,7 \%
\end{aligned}
$$

Perhitungan selanjutnya menggunakan metode NEE. NEE merupakan salah satu metode yang dapat digunakan dalam mengukur efektivitas bersih mesin atau peralatan saat benar-benar beroperasi. Perhitungan NEE membutuhkan data up time, performance efficiency, dan rate of quality product, sehingga terlebih dahulu melakukan perhitungan up time.

Up time merupakan rasio yang diperoleh dari net operation time, dengan cara mengurangi operation time dengan downtime lalu dibagi dengan operation time. Berikut data perhitungan up time. 
Tabel 5. Hasil Perhitungan Up Time

\begin{tabular}{lccc}
\hline \multicolumn{1}{c}{ Bulan } & $\begin{array}{c}\text { Operation Time } \\
\text { (Menit) }\end{array}$ & $\begin{array}{c}\text { Downtime } \\
\text { (Menit) }\end{array}$ & $\begin{array}{c}\text { Up Time } \\
(\%)\end{array}$ \\
\hline Januari 2016 & 28662 & 1173 & 95,9 \\
Februari 2016 & 28095,6 & 1844,4 & 93,4 \\
Maret 2016 & 29110 & 2165 & 92,6 \\
April 2016 & 30199,8 & 2080,2 & 93,1 \\
Mei 2016 & 28669,8 & 1345,2 & 95,3 \\
\hline
\end{tabular}

Perhitungan up time pada bulan Januari 2016 sebagai berikut:

$$
\begin{aligned}
\text { Up Time } & =\frac{\text { Operation Time-Downtime }}{\text { Operation Time }} \times 100 \% \\
& =\frac{28662 \text { Menit-1173 Menit }}{28662 \text { Menit }} \times 100 \% \\
& =95,9 \%
\end{aligned}
$$

Perhitungan Nilai NEE

NEE dapat diketahui dengan mengalikan up time, performance efficiency, serta rate of quality product. Berikut hasil perhitungan NEE pada mesin flame cutting dan plasma cutting.

Tabel 6. Hasil Perhitungan Net Equipment Effectiveness

\begin{tabular}{lcccc}
\hline \multicolumn{1}{c}{ Bulan } & $\begin{array}{c}\text { Up Time } \\
(\boldsymbol{\%})\end{array}$ & $\begin{array}{c}\text { Performance Efficiency } \\
(\boldsymbol{\%})\end{array}$ & $\begin{array}{c}\text { Rate of Quality Product } \\
(\boldsymbol{\%})\end{array}$ & $\begin{array}{c}\text { NEE } \\
(\boldsymbol{\%})\end{array}$ \\
\hline Januari 2016 & 95,9 & 86,1 & 89,1 & 74,0 \\
Februari 2016 & 93,4 & 86,4 & 89,1 & 71,9 \\
Maret 2016 & 92,6 & 86,7 & 83,7 & 67,2 \\
April 2016 & 93,1 & 86,0 & 85,4 & 68,4 \\
Mei 2016 & 95,3 & 86,7 & 88,3 & 72,9 \\
\hline
\end{tabular}

Perhitungan NEE pada bulan Januari 2016 sebagai berikut:

$$
\begin{aligned}
\text { NEE } & =(\text { Up Time } \times \text { Performance Efficiency } \times \text { Rate of Quality Product }) \times 100 \% \\
& =(0,959 \times 0,861 \times 0,891) \times 100 \% \\
& =74,0 \%
\end{aligned}
$$

Perhitungan Nilai TEEP

Perhitungan selanjutnya menggunakan metode TEEP. TEEP digunakan untuk mengukur produktivitas mesin selama kegiatan produksi berlangsung. TEEP mengukur OEE dengan membandingkannya terhadap waktu dalam kalender. Perhitungan TEEP mempertimbangkan nilai dari loading portion serta OEE.

Loading portion merupakan porsi yang menunjukkan persentase dari total waktu kalender dan pada kenyataannya dijadwalkan untuk berjalannya operasi. Berikut hasil perhitungan loading portion.

Tabel 7. Hasil Perhitungan Loading Portion

\begin{tabular}{lccccc}
\hline \multicolumn{1}{c}{ Bulan } & $\begin{array}{c}\text { Hari Kerja } \\
\text { (Hari) }\end{array}$ & $\begin{array}{c}\text { Jumlah Hari } \\
\text { (Hari) }\end{array}$ & $\begin{array}{c}\text { Schedule Time } \\
\text { (Menit) }\end{array}$ & $\begin{array}{c}\text { Calendar Time } \\
\text { (Menit) }\end{array}$ & $\begin{array}{c}\text { Loading Portion } \\
\text { (\%) }\end{array}$ \\
\hline Januari 2016 & 24 & 31 & 34560 & 44640 & 77,4 \\
Februari 2016 & 24 & 29 & 34560 & 41760 & 82,8 \\
Maret 2016 & 25 & 31 & 36000 & 44640 & 80,6 \\
April 2016 & 26 & 30 & 37440 & 43200 & 86,7 \\
Mei 2016 & 24 & 31 & 34560 & 44640 & 77,4 \\
\hline
\end{tabular}




\section{Arif Junisman Mendrofa, Tri Mulyanto}

Schedule time diperoleh dengan mengalikan hari kerja dengan jumlah menit selama 24 jam kerja yaitu 1440 menit, sementara itu calendar time diperoleh dengan mengalikan jumlah hari pada setiap bulan dengan jumlah menit selama 24 jam kerja yaitu 1440 menit. Perhitungan loading portion pada bulan Januari 2016 sebagai berikut:

$$
\begin{aligned}
\text { Loading Portion } & =\frac{\text { Schedule Time }}{\text { Calendar Time }} \times 100 \% \\
& =\frac{34560 \text { Menit }}{44640 \text { Menit }} \times 100 \% \\
& =77,4 \%
\end{aligned}
$$

Persentase dari TEEP dapat diketahui setelah mengalikan nilai dari loading portion dengan nilai OEE mesin flame cutting dan plasma cutting. Berikut hasil perhitungan TEEP pada mesin flame cutting dan plasma cutting.

Tabel 8. Hasil Perhitungan Total Effective Equipment Productivity

\begin{tabular}{lccc}
\hline \multicolumn{1}{c}{ Bulan } & $\begin{array}{c}\text { Loading Portion } \\
(\boldsymbol{\%})\end{array}$ & $\begin{array}{c}\text { OEE } \\
(\boldsymbol{\%})\end{array}$ & $\begin{array}{c}\text { TEEP } \\
(\boldsymbol{\%})\end{array}$ \\
\hline Januari 2016 & 77,4 & 73.7 & 57,0 \\
Februari 2016 & 82,8 & 72,2 & 59,8 \\
Maret 2016 & 80,6 & 67,6 & 54,5 \\
April 2016 & 86,7 & 68,7 & 59,6 \\
Mei 2016 & 77,4 & 73,1 & 56,6 \\
\hline
\end{tabular}

Perhitungan TEEP pada bulan Januari 2016 sebagai berikut:

$$
\begin{aligned}
\text { TEEP } & =(\text { Loading Portion } \times \text { OEE }) \times 100 \% \\
& =(0,774 \times 0,737) \times 100 \% \\
& =57,0 \%
\end{aligned}
$$

Perhitungan Six Big Losses

Perhitungan yang juga dilakukan yaitu menentukan six big losses untuk mengetahui faktor yang memberikan kontribusi terbesar sehingga efektivitas penggunaan mesin flame cutting dan plasma cutting belum mencapai nilai world class OEE. Equipment failures merupakan kerugian akibat kerusakan mesin flame cutting dan plasma cutting secara tibatiba dan tidak diinginkan terjadi, karena menyebabkan mesin tidak dapat beroperasi untuk menghasilkan output. Berikut hasil perhitungan equipment failures pada mesin flame cutting dan plasma cutting.

Tabel 9. Hasil Perhitungan Equipment Failures Loss

\begin{tabular}{lccc}
\hline \multicolumn{1}{c}{ Bulan } & $\begin{array}{c}\text { Breakdown Time } \\
\text { (Menit) }\end{array}$ & $\begin{array}{c}\text { Loading Time } \\
\text { (Menit) }\end{array}$ & $\begin{array}{c}\text { Equipment Failures Loss } \\
(\mathbf{\%})\end{array}$ \\
\hline Januari 2016 & 625,2 & 29835 & 2,1 \\
Februari 2016 & 1293,6 & 29940 & 4,3 \\
Maret 2016 & 1544,4 & 31275 & 4,9 \\
April 2016 & 1471,8 & 32280 & 4,6 \\
Mei 2016 & 785,4 & 30015 & 2,6 \\
\hline \multicolumn{1}{c}{ Total } & $\mathbf{5 7 2 0 , 4}$ & & \\
\hline
\end{tabular}

Perhitungan equipment failures loss pada bulan Januari 2016 sebagai berikut:

$$
\begin{aligned}
\text { Equipment Failures Loss } & =\frac{\text { Breakdown Time }}{\text { Loading Time }} \times 100 \% \\
& =\frac{625,2 \text { Menit }}{29835 \text { Menit }} \times 100 \% \\
& =2,1 \%
\end{aligned}
$$


Setup and adjustment merupakan kerugian akibat kegiatan pemasangan dan penyetelan sparepart dari mesin flame cutting dan plasma cutting, termasuk waktu penyesuaian mesin (adjustment) serta waktu selama proses penggantian plat besi hitam yang akan dipotong berikutnya. Berikut hasil perhitungan persentase kerugian dari setup and adjustment pada mesin flame cutting dan plasma cutting.

Tabel 10. Hasil Perhitungan Setup and Adjustment Loss

\begin{tabular}{lccc}
\hline \multicolumn{1}{c}{ Bulan } & $\begin{array}{c}\text { Set-up and Adjustment Time } \\
\text { (Menit) }\end{array}$ & $\begin{array}{c}\text { Loading Time } \\
\text { (Menit) }\end{array}$ & $\begin{array}{c}\text { Set-up and Adjustment Loss } \\
(\%)\end{array}$ \\
\hline Januari 2016 & 387,6 & 29835 & 1,3 \\
Februari 2016 & 375,6 & 29940 & 1,3 \\
Maret 2016 & 410,4 & 31275 & 1,3 \\
April 2016 & 396 & 32280 & 1,2 \\
Mei 2016 & 372,6 & 30015 & 1,2 \\
\hline \multicolumn{1}{c}{ Total } & $\mathbf{1 9 4 2 , 2}$ & \\
\hline
\end{tabular}

Perhitungan setup and adjustment loss pada bulan Januari 2016 sebagai berikut:

Set - up and Adjustment Loss $=\frac{\text { Set-up and Adjustment Time }}{\text { Loading Time }} \times 100 \%$

$$
\begin{aligned}
& =\frac{387,6 \text { Menit }}{29835 \text { Menit }} \times 100 \% \\
& =1,3 \%
\end{aligned}
$$

Idling and minor stoppages disebabkan oleh kejadian-kejadian seperti pemberhentian mesin sejenak, pembersihan, dan kemacetan mesin. Berdasarkan data kegiatan-kegiatan dalam waktu downtime, maka yang termasuk dari waktu yang tidak produktif (nonproductive time) dalam parameter idling and minor stoppages adalah kegiatan pembersihan mesin. Berikut hasil perhitungan idling and minor stoppages pada mesin flame cutting dan plasma cutting.

Tabel 11. Hasil Perhitungan Idling and Minor Stoppages

\begin{tabular}{lccc}
\hline \multicolumn{1}{c}{ Bulan } & $\begin{array}{c}\text { Nonproductive Time } \\
\text { (Menit) }\end{array}$ & $\begin{array}{c}\text { Loading Time } \\
\text { (Menit) }\end{array}$ & $\begin{array}{c}\text { Idling and Minor Stoppages Loss } \\
(\%)\end{array}$ \\
\hline Januari 2016 & 229,2 & 29835 & 0,8 \\
Februari 2016 & 240 & 29940 & 0,8 \\
Maret 2016 & 272,4 & 31275 & 0,9 \\
April 2016 & 276 & 32280 & 0,9 \\
Mei 2016 & 247,8 & 30015 & 0,8 \\
\hline \multicolumn{1}{c}{ Total } & $\mathbf{1 2 6 5 , 4}$ & & \\
\hline
\end{tabular}
berikut:

Perhitungan idling and minor stoppages loss pada bulan Januari 2016 sebagai

$$
\begin{aligned}
\text { Idling and Minor Stoppages Loss } & =\frac{\text { Nonproductive Time }}{\text { Loading Time }} \times 100 \% \\
& =\frac{229,2 \text { Menit }}{29835 \text { Menit }} \times 100 \% \\
& =0,8 \%
\end{aligned}
$$

Reduce speed losses disebabkan oleh mesin tidak bekerja secara optimal, dalam hal ini terjadi penurunan kecepatan mesin. Berikut hasil perhitungan reduce speed loss pada mesin flame cutting dan plasma cutting. 
Analisis Pengukuran Total Efektivitas Mesin Flame Cutting dan Plasma Cutting pada Perusahaan Industri Strategis

Arif Junisman Mendrofa, Tri Mulyanto

Tabel 12. Hasil Perhitungan Reduce Speed Loss

\begin{tabular}{lccccc}
\hline \multicolumn{1}{c}{ Bulan } & $\begin{array}{c}\text { Operation Time } \\
\text { (Menit) }\end{array}$ & $\begin{array}{c}\text { Waktu Siklus Ideal } \\
\text { (Menit/Unit) }\end{array}$ & $\begin{array}{c}\text { Total Produksi } \\
\text { (Unit) }\end{array}$ & $\begin{array}{c}\text { Loading Time } \\
\text { (Menit) }\end{array}$ & $\begin{array}{c}\text { Reduce Speed Loss } \\
(\%)\end{array}$ \\
\hline Januari 2016 & 28662 & 31,28 & 789 & 29835 & 13,3 \\
Februari 2016 & 28096 & 32,82 & 740 & 29940 & 12,7 \\
Maret 2016 & 29110 & 34,47 & 732 & 31275 & 12,4 \\
April 2016 & 30200 & 35,54 & 731 & 32280 & 13,1 \\
Mei 2016 & 28670 & 31,61 & 786 & 30015 & 12,7 \\
\hline
\end{tabular}

Perhitungan reduce speed loss pada bulan Januari 2016 sebagai berikut:

$$
\begin{aligned}
\text { Reduce Speed Loss } & =\frac{\text { Operation Time }-(\text { Waktu Siklus Ideal } \times \text { Total Produksi) }}{\text { Loading Time }} \times 100 \% \\
& =\frac{28662 \text { Menit }-(31,28 \text { Menit } / \text { Unit } \times 789 \text { Unit })}{29835 \text { Menit }} \times 100 \% \\
& =13,3 \%
\end{aligned}
$$

Hasil perhitungan persentase reduce speed loss selanjutnya digunakan untuk mengetahui reduce speed loss time pada setiap bulan berdasarkan perbandingan persentase reduce speed loss dengan loading time. Berikut hasil perhitungan reduce speed loss time pada mesin flame cutting dan plasma cutting.

Tabel 13. Hasil Perhitungan Reduce Speed Loss Time

\begin{tabular}{lccc}
\hline \multicolumn{1}{c}{ Bulan } & $\begin{array}{c}\text { Loading Time } \\
\text { (Menit) }\end{array}$ & $\begin{array}{c}\text { Reduce Speed Loss } \\
(\%)\end{array}$ & $\begin{array}{c}\text { Reduce Speed Loss Time } \\
\text { (Menit) }\end{array}$ \\
\hline Januari 2016 & 29835 & 13,3 & 3968,1 \\
Februari 2016 & 29940 & 12,7 & 3802,4 \\
Maret 2016 & 31275 & 12,4 & 3878,1 \\
April 2016 & 32280 & 13,1 & 4228,7 \\
Mei 2016 & 30015 & 12,7 & 3811,9 \\
\hline \multicolumn{1}{c}{ Total } & & & 19689,1 \\
\hline
\end{tabular}

Perhitungan reduce speed loss time pada bulan Januari 2016 sebagai berikut:

Reduce Speed Loss Time $=$ Loading Time $\times\left(\frac{\text { Reduce Speed Loss }}{100}\right)$

$$
\begin{aligned}
& =29835 \text { Menit } \times\left(\frac{13,3}{100}\right) \\
& =3968,1 \text { Menit }
\end{aligned}
$$

Defect losses merupakan kerugian disebabkan komponen-komponen grill lampu depan memiliki kekurangan (cacat) setelah dipotong menggunakan mesin flame cutting dan plasma cutting. Berikut hasil perhitungan defect loss.

Tabel 14. Hasil Perhitungan Defect Loss

\begin{tabular}{lccccc}
\hline \multicolumn{1}{c}{ Bulan } & $\begin{array}{c}\text { Waktu Siklus Ideal } \\
\text { (Menit/Unit) }\end{array}$ & $\begin{array}{c}\text { Produk Cacat } \\
\text { (Unit) }\end{array}$ & $\begin{array}{c}\text { Loading Time } \\
\text { (Menit) }\end{array}$ & $\begin{array}{c}\text { Defect Loss } \\
(\%)\end{array}$ & $\begin{array}{c}\text { Defect Loss Time } \\
\text { (Menit) }\end{array}$ \\
\hline Januari 2016 & 31,28 & 86 & 29835 & 9,0 & 2685,2 \\
Februari 2016 & 32,82 & 81 & 29940 & 8,9 & 2664,7 \\
Maret 2016 & 34,47 & 119 & 31275 & 13,1 & 4097 \\
April 2016 & 35,54 & 107 & 32280 & 11,8 & 3809 \\
Mei 2016 & 31,61 & 92 & 30015 & 9,7 & 2911,5 \\
\hline \multicolumn{1}{c}{ Total } \\
\hline
\end{tabular}

Perhitungan defect loss pada bulan Januari 2016 sebagai berikut:

Defect Loss $=\frac{\text { Waktu Siklus Ideal } \times \text { Produk Cacat }}{\text { Loading Time }} \times 100 \%$ 


$$
\begin{aligned}
& =\frac{31,28 \text { Menit } / \text { Unit } \times 86 \text { Unit }}{29835 \text { Menit }} \times 100 \% \\
& =9,0 \%
\end{aligned}
$$

Perhitungan defect loss time pada bulan Januari 2016 sebagai berikut:

$$
\begin{aligned}
\text { Defect Loss Time } & =\text { Loading Time } \times\left(\frac{\text { Defect Loss }}{100}\right) \\
& =29835 \text { Menit } \times\left(\frac{9,0}{100}\right) \\
& =29835 \text { Menit } \times 0,09 \\
& =2685,2 \text { Menit }
\end{aligned}
$$

Reduce yield losses merupakan kerugian yang terjadi pada awal waktu produksi hingga mencapai kondisi yang stabil. Akibat dari kerugian ini yaitu komponen-komponen grill lampu depan yang dipotong tidak sesuai standar, disebabkan perbedaan kualitas produk pada waktu mesin flame cutting dan plasma cutting pertama kali dinyalakan dengan waktu mesin tersebut telah stabil beroperasi. Berikut hasil perhitungan reduce yield loss.

Tabel 15. Hasil Perhitungan Reduce Yield Loss

\begin{tabular}{lccccc}
\hline \multicolumn{1}{c}{ Bulan } & $\begin{array}{c}\text { Waktu Siklus Ideal } \\
\text { (Menit/Unit) }\end{array}$ & $\begin{array}{c}\text { Produk Cacat pada } \\
\text { Awal Produksi (Unit) }\end{array}$ & $\begin{array}{c}\text { Loading Time } \\
\text { (Menit) }\end{array}$ & $\begin{array}{c}\text { Reduce Yield Loss } \\
(\boldsymbol{\%})\end{array}$ & $\begin{array}{c}\text { Reduce Yield Loss Time } \\
\text { Menit) }\end{array}$ \\
\hline Januari 2016 & 31,28 & 10 & 29835 & 1,0 & 298,4 \\
Februari 2016 & 32,82 & 6 & 29940 & 0,7 & 209,6 \\
Maret 2016 & 34,47 & 17 & 31275 & 1,9 & 594,2 \\
April 2016 & 35,54 & 13 & 32280 & 1,4 & 451,9 \\
Mei 2016 & 31,61 & 9 & 30015 & 0,9 & 270,1 \\
\hline \multicolumn{7}{c}{ Total } \\
\hline
\end{tabular}

Perhitungan reduce yield loss pada bulan Januari 2016 sebagai berikut:

$$
\begin{aligned}
\text { Reduce Yield Loss } & =\frac{\text { Waktu Siklus Ideal } \times \text { Produk Cacat pada Awal Produksi }}{\text { Loading Time }} \times 100 \% \\
& =\frac{31,28 \text { Menit } / \text { Unit } \times 10 \text { Unit }}{29835 \text { Menit }} \times 100 \% \\
& =0,01 \times 100 \% \\
& =1,0 \%
\end{aligned}
$$

Persentase reduce yield loss selanjutnya digunakan untuk perhitungan reduce yield loss time. Perhitungan reduce yield loss time pada bulan Januari 2016 sebagai berikut:

$$
\begin{aligned}
\text { Reduce Yield Loss Time } & =\text { Loading Time } \times\left(\frac{\text { Reduce Yield Loss }}{100}\right) \\
& =29835 \text { Menit } \times\left(\frac{1,0}{100}\right) \\
& =29835 \text { Menit } \times 0,01 \\
& =298,4 \text { Menit }
\end{aligned}
$$

Analisis Perbandingan Nilai OEE, NEE, dan TEEP

Nilai OEE, NEE, dan TEEP yang telah diperoleh menunjukkan total efektivitas dari mesin flame cutting dan plasma cutting dengan berbagai parameter yang ada. Perbandingan nilai total efektivitas mesin flame cutting dan plasma cutting menggunakan OEE, NEE, dan TEEP ditampilkan melalui grafik perbandingan tren nilai pada gambar berikut ini. 


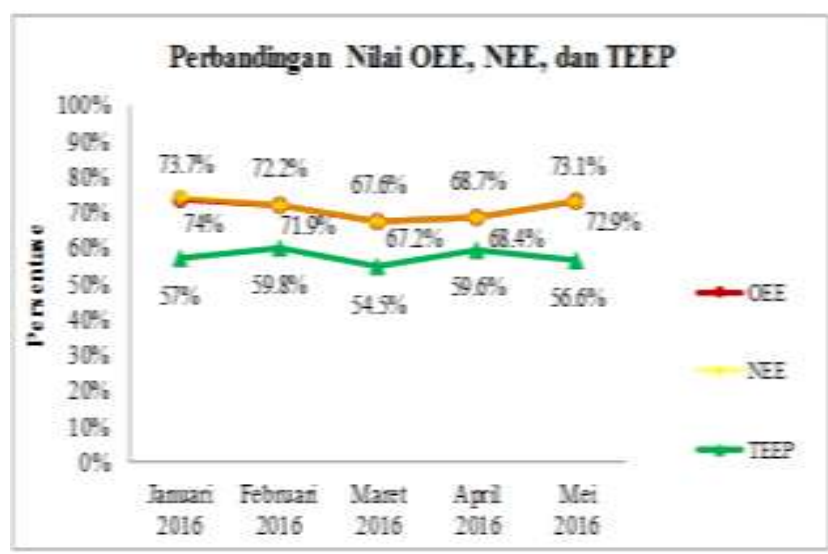

Gambar 2. Grafik Perbandingan Tren Nilai OEE, NEE, dan TEEP

Berdasarkan hasil perhitungan total efektivitas mesin flame cutting dan plasma cutting menggunakan OEE, NEE, serta TEEP, maka diketahui jika nilai OEE dan NEE dari mesin flame cutting dan plasma cutting rata-rata berada di atas $60 \%$ serta tidak menunjukkan perbedaan yang signifikan. Sementara itu, nilai TEEP cukup signifikan perbedaannya dari nilai OEE serta NEE dan berada di bawah $60 \%$ mulai dari bulan Januari 2016 hingga Mei 2016.

Hasil pengukuran total efektivitas mesin flame cutting dan plasma cutting menggunakan 3 metode, baik OEE, NEE dan TEEP masih rendah dan belum ideal. Perusahaan perlu mengidentifikasi kerugian-kerugian yang telah terjadi selama ini, lalu menentukan penyebab dari kerugian tersebut, sehingga dapat dilakukan perbaikan oleh perusahaan untuk mencapai tingkat perusahaan kelas dunia.

\section{KESIMPULAN}

Kesimpulan merupakan jawaban dari tujuan penulisan. Berikut kesimpulan dari penelitian yang telah dilakukan pada perusahaan industri strategis. Total efektivitas kerja mesin flame cutting dan plasma cutting diukur dengan menggunakan 3 metode, antara lain OEE, NEE, dan TEEP. Namun masih berada di bawah world class OEE sebesar 85\% berdasarkan Japan Institute for Plant Maintenance (JIPM). Persentase NEE dan TEEP berturut-turut dari bulan Januari hingga Mei 2016 juga masih termasuk rendah. Six big losses dari mesin flame cutting dan plasma cutting terdiri dari equipment failures, setup and adjustment, idling and minor stoppages, reduce speed losses, defect losses, dan reduce yield losses. Faktor-faktor penyebab menurunnya efektivitas mesin flame cutting dan plasma cutting akibat dari tingginya reduce speed losses antara lain faktor manusia, metode, mesin, dan material. Sementara itu, faktor-faktor penyebab menurunnya efektivitas mesin flame cutting dan plasma cutting akibat dari tingginya defect losses, antara lain faktor manusia, metode, mesin, material, dan lingkungan. Usulan untuk meningkatkan efektivitas kerja mesin flame cutting dan plasma cutting terbagi dalam beberapa faktor sesuai penyebab menurunnya efektivitas mesin yang terjadi, diantaranya adalah menerapkan program pelatihan serta evaluasi rutin, adanya pembaharuan perhitungan waktu siklus ideal dengan membandingkannya pada waktu siklus aktual, menerapkan autonomous maintenance, pembersihan plat dari berbagai kotoran atau debu, serta menerapkan budaya kerja 5S.

\section{DAFTAR PUSTAKA}

[1] A. Ahyari, 2002. Manajemen Produksi: Pengendalian Produksi. Edisi Ke Empat, BPFE, Yogyakarta.

[2] S. Assauri, 2004. Manajemen dan Operasi. Lembaga Penerbitan FEUI, Jakarta. 
[3] A. Corder, 1992. Teknik Manajemen Pemeliharaan. diterjemahkan, K. Hadi, Erlangga, Jakarta.

[4] A. Daryus, 2007. Diktat Manajemen Pemeliharaan Mesin. Universitas Darma Persada, Jakarta.

[5] F. Kurniawan, 2013. Teknik dan Aplikasi Manajemen Perawatan Industri. Edisi Pertama, Graha Ilmu, Yogyakarta.

[6] F.D., Setiawan, 2008. Perawatan Mekanikal Mesin Produksi. Maximus, Yogyakarta.

[7] Suharto, 1991. Manajemen Perawatan Mesin. Rineka Cipta, Anggota Ikapi, Jakarta.

[8] S. Nakajima, 1988. Introduction To TPM (Total Productive Maintenance). First Edition, Productivity Inc., Cambridge.

[9] M. Hasriyono, 2009. Evaluasi Efektivitas Mesin dengan Penerapan Total Productive Maintenance (TPM) di PT. Hadi Baru. Skripsi Teknik Industri, Universitas Sumatera Utara, Medan (Diunduh pada tanggal 17 Mei 2017).

[10] Malik, N. Ainul, dan M. Hamsal. 2013. Pengukuran Kinerja Operasional Melalui Implementasi Total Productive Maintenance di PT. XYZ. Jurnal Bisnis dan Kewirausahaan, vol. 1, no.2, Fakultas Ekonomi, Universitas Indonesia, Jakarta (Diunduh pada tanggal 26 April 2017).

[11] A. Hanifa, 2013. Analisis Penerapan Kebijakan Total Productive Maintenance Pada Proses Produksi Transformer. Teknik Industri, Universitas Diponegoro, Semarang (Diunduh pada tanggal 14 Juni 2017).

[12] S. Wignjosoebroto, 2003. Pengantar Teknik \& Manajemen Industri. Edisi Pertama, Guna Widya, Surabaya.

[13] S. Wibowo, 2007. Pedoman Mengelola Perusahaan Kecil. Edisi Revisi, Penebar Swadaya, Yogyakarta.

[14] Alvira, Dianra, Y. Helianty dan H. Prassetiyo. 2015. Usulan Peningkatan Overall Equipment Effectiveness (OEE) pada Mesin Tapping Manual dengan Meminimumkan Six Big Losses. Jurnal Online Institut Teknologi Nasional, vol.3, no.3, (Diunduh pada tanggal 20 Mei 2017).

[15] Ibrahim, W. Sugar. 2012. Analisa Nilai Overall Equipment Efectivness (OEE), Net Equipment Efectivness (NEE) dan Total Effective Equipment Productivity (TEEP) pada Mesin Inject Plastik E.221 dan Mesin Lipat Kertas E.237 di Line AFPL02. Skripsi Teknik Industri, Universitas Mercu Buana, Jakarta (Diunduh pada tanggal 15 April 2017).

[16] S. Oktaria, 2011. Perhitungan dan Analisa Nilai Overall Equipment Effectiveness (OEE) pada Proses Awal Pengolahan Kelapa Sawit (Studi Kasus: PT. X). Skripsi Teknik Industri, Universitas Indonesia, Depok (Diunduh pada tanggal 20 Juni 2017).

[17] D.H. Stamatis, 2011. The OEE Primer, Understanding Overall Equipment Effectiveness, Reliability, and Maintainability. CRC Press, Florida.

[18] R. C. Hansen, 2001. Overall Equipment Effectiveness: Powerful Production/ Maintenance Tool for Incrased Profits, First Edition. Industrial Press Inc., New York. 